\title{
Review \\ Clinical and Immunological Biomarkers for Systemic Lupus Erythematosus
}

\author{
Haitao Yu ${ }^{1, *}$, Yasuo Nagafuchi ${ }^{2,3, *(1)}$ and Keishi Fujio ${ }^{2}$ \\ 1 Department of Laboratory Medicine, The First Hospital of Lanzhou University, Lanzhou University, \\ Lanzhou 730000, China \\ 2 Department of Allergy and Rheumatology, Graduate School of Medicine, The University of Tokyo, \\ Tokyo 113-8655, Japan; FUJIOK-INT@h.u-tokyo.ac.jp \\ 3 Department of Functional Genomics and Immunological Disease, Graduate School of Medicine, \\ The University of Tokyo, Tokyo 113-8655, Japan \\ * Correspondence: yuhaitao7707@163.com (H.Y.); nagafuchi@g.ecc.u-tokyo.ac.jp (Y.N.); \\ Tel.: +86-0931-8356-241 (H.Y.); +81-3-3815-5411 (Y.N.)
}

check for

updates

Citation: Yu, H.; Nagafuchi, Y.;

Fujio, K. Clinical and Immunological

Biomarkers for Systemic Lupus

Erythematosus. Biomolecules 2021, 11,

928. https://doi.org/10.3390/

biom 11070928

Academic Editor: Carlo Perricone

Received: 19 May 2021

Accepted: 17 June 2021

Published: 22 June 2021

Publisher's Note: MDPI stays neutral with regard to jurisdictional claims in published maps and institutional affiliations.

Copyright: (c) 2021 by the authors. Licensee MDPI, Basel, Switzerland. This article is an open access article distributed under the terms and conditions of the Creative Commons Attribution (CC BY) license (https:/ / creativecommons.org/licenses/by/ $4.0 /)$.

\begin{abstract}
Systemic lupus erythematosus (SLE) is characterized by immune system dysfunction and is clinically heterogeneous, exhibiting renal, dermatological, neuropsychiatric, and cardiovascular symptoms. Clinical and physiological assessment is usually inadequate for diagnosing and assessing pathophysiological processes in SLE. Clinical and immunological biomarkers could play a critical role in improving diagnosis, assessment, and ultimately, control of SLE. This article reviews clinical and immunological biomarkers that could diagnose and monitor disease activity in SLE, with and without organ-specific injury. In addition, novel SLE biomarkers that have been discovered through "omics" research are also reviewed.
\end{abstract}

Keywords: systemic lupus erythematosus; biomarkers; diagnosis; monitoring; omics

\section{Introduction}

Systemic lupus erythematosus (SLE) is a systemic autoimmune disease characterized by aberrant activity of the immune system [1] and presents with a wide range of clinical manifestations, including renal, dermatological, neuropsychiatric, and cardiovascular symptoms [2]. The incidence of SLE is 0.3-31.5 in 100,000 per year, and the adjusted prevalence is approaching, or even exceeding, 50-100 in 100,000 [3]. Unfortunately, there appears to be a trend of increasing SLE prevalence with time [4]. Healthcare-related costs of SLE are related to disease severity and the types of organ(s) involved [5]. Patients with SLE had mean annual costs of about $\$ 21,000-\$ 53,000$ in the USA [6], and their mean annual direct medical cost was $€ 2600-€ 4800$ in Europe [7].

SLE is an important social and public health problem, as the medication and multidisciplinary approach for treating SLE can only control the symptoms and delay the progression of the disease but cannot cure it completely [1]. It is critical to improve the ability to diagnose SLE early for effective treatment. Therefore, biomarkers, especially immunological biomarkers, have emerged to help better diagnose SLE and assess its pathophysiological processes, with the ultimate goal of improving control of the disease. The aim of the current study was to review immunological biomarkers for SLE diagnosis and pathophysiological process assessment.

\section{Characteristics of Biomarkers}

A biomarker is defined as a measurable indicator of a normal biological process, a pathogenic process, or a response to drug exposure or intervention [8]. Recently, biomarkers were redefined such that they must have a specific physical sign or cellular, biochemical, molecular, or genetic character and can be used to detect and/or monitor a biologic process 
or morbid state by a qualitative and/or quantitative test [9]. Blood, urine, or tissues can be measured for biomarkers [10]. In recent years, biomarkers have been widely employed in the diagnosis, prediction, assessment, and management of several diseases, such as SLE, diabetes, heart disease, and cancer [11].

Biomarkers play a crucial role in diagnosing SLE, classifying SLE complications, assessing SLE disease activity, and reflecting the therapeutic effect of interventions for SLE. Common biomarkers for SLE and their measurement sites in patients with SLE are highlighted in Figure 1. Finding an ideal biomarker for SLE is challenging because it should have the following characteristics: (1) reflect the underlying pathophysiology or treatment target; (2) have reliability, validity, high predictive values, and high sensitivity and specificity; (3) have the ability to monitor SLE activity or flares; (4) are reliably measured in tissues, cells, or fluids, and not be influenced by other factors or comorbidities; and (5) are stable, reproducible, easily detected, and testing should be readily available in most laboratories at a reasonable cost $[9,12]$. It should be noted that reproducibility and reliability may be affected by laboratory errors, specific techniques, or changes in storage [13]. Because SLE can cause damage to various organs, has a complex pathogenesis, and displays heterogeneous clinical manifestations, one particular biomarker may only reflect one specific aspect of SLE but not be useful for reflecting the state of the disease as a whole [14,15].

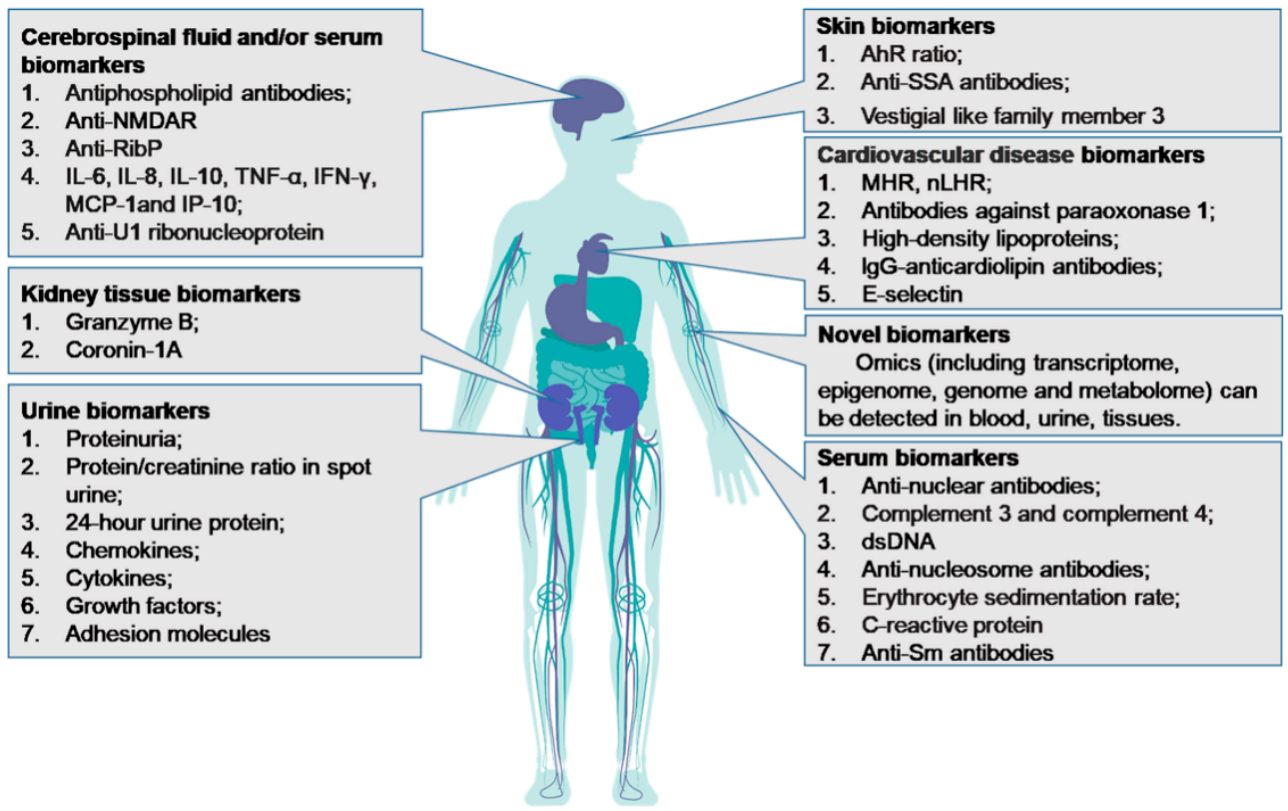

Figure 1. Common biomarkers for SLE and their measurement sites in patients with SLE. AhR ratio: the ratio of aryl hydrocarbon receptor in Th17 cells to that in Treg; anti-NMDAR: antibodies against N-methyl-D-aspartate receptor; anti-RibP: antibodies against ribosomal proteins; anti-SSA: antibodies against Sjogren's syndrome A; dsDNA: double-stranded DNA; IgG: immunoglobulin G; IFN: interferon; IL: interleukin; IP-10: IFN- $\gamma$-inducible protein 10; MCP-1: monocyte chemotactic protein-1; MHR: monocyte-to-high-density lipoprotein cholesterol ratio; nLHR: low-density granulocytes-to-highdensity lipoprotein cholesterol ratio; PON1: antibodies against paraoxonase1; Sm: Smith; TNF: tumor necrosis factor.

\section{Biomarkers for SLE Diagnosis and Classification}

SLE is diagnosed and classified based on a patient's clinical symptoms, signs, and laboratory biomarkers that reflect immune reactivity and inflammation in various organs. It is necessary to develop consistent classification criteria of SLE for research and clinical diagnosis. The most widely used classification criteria for SLE was established by the American College of Rheumatology (ACR) and contains laboratory biomarkers, including proteinuria, urinary casts, hemolytic anemia with reticulocytosis, white blood cells, lym- 
phocytes, platelets, the presence of Smith (Sm) antibody, antinuclear antibody (ANA), DNA antibody, total complement activity, complement (2,3, and 4), and lupus erythematosus (LE) cells [16]. The classification criteria were revised by the Diagnostic and Therapeutic Criteria Committee of the ACR in 1997. The revised criteria removed the marker of "LE cell" and added anticardiolipin antibodies as a biomarker for the immunologic criteria [17]. To improve the criteria's clinical relevance and incorporate new knowledge of the immunological basis of SLE, the Systemic Lupus International Collaborating Clinics (SLICC) group revised and validated the ACR SLE classification criteria in 2012. The SLICC criteria emphasize that at least one immunologic criterion is required for SLE, and ANAs or doublestranded DNA (dsDNA) antibodies can be used for categorizing nephritis compatible with SLE [18]. The SLICC-2012 classification criteria of SLE show improved sensitivity and lower specificity compared to the ACR-1997 classification criteria [18,19]. In 2019, new classification criteria for SLE were developed by the European Alliance of Associations for Rheumatology (EULAR) and the American College of Rheumatology (ACR). Positive ANA is emphasized as an obligatory entry criterion for SLE by the EULAR/ACR-2019 SLE classification, and three immunologic biomarkers (antiphospholipid antibodies, complement proteins, SLE-specific antibodies) and seven clinical indices (constitutional, hematologic, neuropsychiatric, mucocutaneous, serosal, musculoskeletal, renal) are used as additive weighted criteria for SLE [20]. The EULAR/ACR-2019 SLE classification criteria strengthen the role of immunological biomarkers and have a better sensitivity $(96.1 \%)$ and specificity (93.4\%) compared with SLICC-2012 and ACR-1997 [20].

Table 1 categorizes the biomarkers used for SLE classification based on the ACR-1997, SLICC-2012, and EULAR/ACR-2019 criteria. Anti-dsDNA antibodies and hypocomplementemia are required in the classification criteria of SLICC-2012 and EULAR/ACR-2019 but not in the ACR-1997 criteria (Table 1). In patients with early SLE, both EULAR/ACR-2019 and SLICC-2012 criteria are more sensitive than the ACR criteria, and the EULAR/ACR-2019 criteria have excellent specificity [20]. Due to the enhanced sensitivity of the EULAR/ACR2019, patients with SLE could be classified, diagnosed, and treated early [21-23]. Despite the performance of these criteria, SLE diagnosis remains challenging, and some patients with possible SLE disease can still be missed. There are a few reasons for a missed diagnosis of SLE. First, the sensitivity and specificity of current biomarkers are not ideal. Second, high levels of physician skill and experience are required for SLE diagnosis. Finally, few patients with SLE show clinical symptoms in the early stages of disease, making SLE difficult or impossible to diagnose, especially in patients with limited SLE features [24].

Table 1. Biomarkers for SLE in the defined criteria of ACR-1997, SLICC-2012, and EULAR/ACR-2019.

\begin{tabular}{|c|c|c|c|}
\hline Biomarkers & ACR-1997 Criteria & SLICC-2012 Criteria & EULAR/ACR-2019 Criteria \\
\hline Proteinuria & $\begin{array}{c}\text { Persistent proteinuria }>0.5 \mathrm{~g} / 24 \mathrm{~h} \\
\text { or }>3+, \text { if quantitation not } \\
\text { performed }\end{array}$ & $\begin{array}{l}\text { Urine protein to creatinine ratio (or } 24-\mathrm{h} \\
\text { urine protein) representing } 500 \mathrm{mg} \\
\text { protein } / 24 \mathrm{~h}\end{array}$ & $\begin{array}{l}\text { Proteinuria }>0.5 \mathrm{~g} / 24 \mathrm{~h} \text { by } 24-\mathrm{h} \\
\text { urine or equivalent spot urine } \\
\text { protein to creatinine ratio }\end{array}$ \\
\hline Urinary casts & $\begin{array}{l}\text { Cellular casts may be red cell, } \\
\text { hemoglobin, granular, tubular, or } \\
\text { mixed }\end{array}$ & Red blood cell casts & - \\
\hline Hemolytic anemia & $\begin{array}{l}\text { Hemolytic anemia with } \\
\text { reticulocytosis }\end{array}$ & $\begin{array}{l}\text { Direct Coombs' test in the absence of } \\
\text { hemolytic anemia }\end{array}$ & $\begin{array}{l}\text { Evidence of hemolysis, such as } \\
\text { reticulocytosis, low haptoglobin, } \\
\text { elevated indirect bilirubin, } \\
\text { elevated LDH, and positive } \\
\text { Coombs' (direct antiglobulin) test }\end{array}$ \\
\hline White blood cell count & $\begin{array}{c}\text { White blood cell count } \\
<4000 / \mathrm{mm}^{3} \text { on } \\
2 \text { or more occasions; OR } \\
\text { Lymphocyte count }<1500 / \mathrm{mm}^{3} \\
\text { on } 2 \\
\text { or more occasions }\end{array}$ & $\begin{array}{l}\text { White blood cell count }<4000 / \mathrm{mm}^{3} \text { at least } \\
\text { once, in the absence of other known causes } \\
\text { such as Felty's syndrome, drugs, and portal } \\
\text { hypertension; OR Lymphocyte count }< \\
1000 / \mathrm{mm}^{3} \text { at least once, in the absence of } \\
\text { other known causes such as corticosteroids, } \\
\text { drugs, and infection }\end{array}$ & $\begin{array}{l}\text { White blood cell count } \\
\quad<4000 / \mathrm{mm}^{3}\end{array}$ \\
\hline
\end{tabular}


Table 1. Cont.

\begin{tabular}{|c|c|c|c|}
\hline Biomarkers & ACR-1997 Criteria & SLICC-2012 Criteria & EULAR/ACR-2019 Criteria \\
\hline Platelet count & $\begin{array}{l}\text { Platelet count }<100,000 / \mathrm{mm}^{3} \text { in } \\
\text { the absence of offending drugs }\end{array}$ & $\begin{array}{l}\text { Platelet count }<100,000 / \mathrm{mm}^{3} \text { at least once, } \\
\text { in the absence of other known causes such } \\
\text { as drugs, portal hypertension, and } \\
\text { thrombotic thrombocytopenic purpura } \\
\text { immunologic criteria }\end{array}$ & Platelet count $<100,000 / \mathrm{mm}^{3}$ \\
\hline Sm antibody & $\begin{array}{c}\text { Presence of antibodies to } \mathrm{Sm} \\
\text { nuclear antigen }\end{array}$ & Presence of antibodies to Sm nuclear antigen & anti-Sm antibodies \\
\hline $\begin{array}{l}\text { Serologic text for } \\
\text { syphilis }\end{array}$ & $\begin{array}{l}\text { False positive serologic test for } \\
\text { syphilis known to be positive for } \\
\text { at least } 6 \text { months and confirmed } \\
\text { by Treponernapallidun } \\
\text { immobilization or fluorescent } \\
\text { treponemal antibody } \\
\text { absorption test }\end{array}$ & - & - \\
\hline $\begin{array}{l}\text { Antinuclear antibody } \\
\text { levels }\end{array}$ & $\begin{array}{l}\text { An abnormal titer of antinuclear } \\
\text { antibody by immunofluorescence } \\
\text { or an equivalent assay at any } \\
\text { point in time and in the absence of } \\
\text { drugs known to be associated } \\
\text { with "drug-induced } \\
\text { lupus" syndrome }\end{array}$ & ANA level above laboratory reference range & $\begin{array}{c}\text { ANA at a titer of } \geq 1: 80 \text { on HEp-2 } \\
\text { cells or an equivalent positive test } \\
\text { at least once; testing by } \\
\text { immunofluorescence on HEp-2 } \\
\text { cells or a solid-phase ANA } \\
\text { screening immunoassay with at } \\
\text { least equivalent performance is } \\
\text { highly recommended }\end{array}$ \\
\hline DNA antibody & $\begin{array}{l}\text { Antibody to native DNA in } \\
\text { abnormal titer }\end{array}$ & $\begin{array}{l}\text { Anti-dsDNA antibody level above } \\
\text { laboratory reference range (or 2-fold the } \\
\text { reference range if tested by ELISA) }\end{array}$ & $\begin{array}{c}\text { Anti-dsDNA antibodies in an } \\
\text { immunoassay with demonstrated } \\
\geq 90 \% \text { specificity for SLE against } \\
\text { relevant disease controls }\end{array}$ \\
\hline $\mathrm{CH} 50$ & $\mathrm{CH} 50$ & Low CH50 & - \\
\hline Complement 3 & Complement 3 & Low complement 3 & Low complement 3 \\
\hline Complement 4 & Complement 4 & Low complement 4 & Low complement 4 \\
\hline Complement 2 & Complement 2 & - & - \\
\hline $\begin{array}{l}\text { Antiphospholipid } \\
\text { antibody }\end{array}$ & $\begin{array}{l}\text { Antiphospholipid } \\
\text { antibody positivity }\end{array}$ & $\begin{array}{l}\text { Antiphospholipid antibody positivity as } \\
\text { determined by any of the following: positive } \\
\text { test result for lupus anticoagulant; } \\
\text { false-positive test result for rapid plasma } \\
\text { regain; medium- or high-titer anticardiolipin } \\
\text { antibody level (IgA, IgG, or IgM); positive } \\
\text { test result for anti-2-glycoprotein I (IgA, IgG, } \\
\text { or IgM) }\end{array}$ & $\begin{array}{l}\text { Anticardiolipin antibodies (IgA, } \\
\text { IgG, or IgM) at medium or high } \\
\text { titer ( }>40 \text { APL, GPL, or MPL, or } \\
\text { >the } 99 \text { th percentile) or positive } \\
\text { anti- } \beta 2 \text { GPI antibodies (IgA, IgG, } \\
\text { or IgM) or positive } \\
\text { lupus anticoagulant }\end{array}$ \\
\hline
\end{tabular}

ACR: American College of Rheumatology; ANA: antinuclear antibody; anti- $\beta 2$ GPI: anti- $\beta 2$-glycoprotein I; $C H 50$ : total complement activity; dsDNA: double-stranded DNA; ELISA: enzyme-linked immunosorbent assay; EULAR: the European Alliance of Associations for Rheumatology; IgA: immunoglobulin A; IgG: immunoglobulin G; IgM: immunoglobulin M; LDH: lactate dehydrogenase; SLE: systemic lupus erythematosus; SLICC: Systemic Lupus International Collaborating Clinics; Sm: Smith.

\section{Non-Organ-Specific Biomarkers for SLE}

\subsection{Serum ANA}

ANA detected by indirect immunofluorescence (IIF) on HEp-2 cells has long been regarded as a pivotal immunological biomarker in serum for classifying a patient with SLE, as well as assessing eligibility for SLE [25-28]. The ANA test is included in the ACR-1997, SLICC-2012, and EULAR/ACR-2019 criteria [16-18,20]. The presence of IIF-ANA titer of 1:80 or more serves as an obligatory entry criterion of SLE by the EULAR/ACR-2019 criteria [20]. If the patient is positive for ANA, further testing for antigen-specific ANAs, such as dsDNA, Sjögren's syndrome antigen A (SSA (Ro60)), Sjögren's syndrome antigen $\mathrm{B}, \mathrm{Sm}$, and ribonuclear protein should be done. Although ANA is not unique to SLE, it is highly characteristic of SLE and can be used as a biomarker for screening, classification, diagnosis, prognosis, and staging $[25,29]$. ANA tests have high sensitivity, ranging from $90 \%$ to $95 \%$ in SLE patients [30] but a relatively low specificity as they can occur in 5-20\% of healthy controls, especially in older people [31]. The sensitivity of ANA tests may be related to the early detection of SLE [32]. Although ANA tests are essentially universal for 
SLE, a negative ANA test cannot rule out SLE diagnosis. Choi et al. reported that $6.2 \%$ of patients with SLE were ANA-negative [33]. In fact, up to $30 \%$ of patients with SLE screened in clinical trials for new therapies are ANA-negative [34,35]. The inconsistency of ANA results in SLE may be due to variability in IIF-ANA assays, which have discrepant antigen properties (e.g., the combining capacity between molecularly cloned proteins and HEp-2 cells), the effects of nuclear antigens by HEp-2 cells, variability in laboratory routines, or different threshold in positive-ANA judgment [36-38]. Therefore, a standard ANA test with a consistent fine specificity, detection method, and laboratory protocol should be established in the future.

Although the IIF assay on HEp-2 cells is widely used for detecting ANA [25], enzymelinked immunosorbent assay (ELISA) has also been used [29]. Antigens used in ELISA assays vary in source and composition, and they can be a mixture of proteins, DNA, and cell extracts [38]. IIF and ELISA are two kinds of techniques and have different sensitivities and specificities. IIF-ANA has a high sensitivity because multiple antibodies are detected simultaneously. However, this method also has some defects, such as being time-consuming, having a higher rate of false positives, and being difficult to categorize the specific antibody type. ELISA has a high sensitivity, as it uses purified antigens. Regardless of the test chosen, anyone testing for ANA should be familiar with the specific assay being used, including its specificity and sensitivity [29,39].

\subsection{Serum Complement 3 (C3) and Complement 4 (C4)}

Immune complexes can activate complements [40]. Serum C3 and C4 are widely used to assess the presence of biologically active immune complexes [41] and monitor disease activity. Low serum levels of C3 or C4 are considered immunological biomarkers in the SLICC-2012 SLE classification criteria. As one of the immunological criteria, low levels of both C3 and C4 are weighted higher than having low levels of either C3 or C4 alone in the EULAR/ACR-2019 classification criteria for SLE [22]. Patients with low levels of both C3 and C4 are more readily diagnosed with SLE than patients who exhibitlow C3 or C4, and patients with either low C3 or low C4 together with a positive ANA test showed $94.3 \%$ specificity for an SLE diagnosis, while patients with simultaneously low C3 and C4 levels combined with a positive ANA showed 97.6\% specificity for an SLE diagnosis [42]. Furthermore, decreased levels of C3 and C4 can precede a clinically evident flare and positively correlate with SLE disease activity [43], especially in SLE complicated with renal or hematologic flares [44]. However, owing to the low specificity of C3 and C4 in diagnosing SLE, the reliability of C3 and C4 levels as biomarkers can be limited in diagnosing SLE and assessing disease activity in some patients, especially if used in isolation [24].

\subsection{Anti-Nucleosome Antibodies (ANuA)}

The prevalence of ANuA in SLE varies from 50\% to $100 \%$, and ANuA can be combined with clinical findings and other laboratory tests for diagnosing SLE and drug-induced lupus [45]. The presence of $\mathrm{ANuA}$ is related to glomerulonephritis and disease activity in SLE patients [45]. Moreover, the sensitivity of the ANuA assay for SLE is $61 \%$, and the specificity is $94 \%$. The overall positive likelihood ratio of $\mathrm{ANuA}$ is 13.81 , and the negative likelihood ratio is 0.38 . The probability that a subject with positive ANuA has SLE is 41 times greater than a subject with negative $\mathrm{ANuA}[46]$.

\subsection{Erythrocyte Sedimentation Rate (ESR) and C-Reactive Protein (CRP)}

In clinical practice, high ESR values, along with low CRP levels, are a key sign of inflammation in SLE and can be used for monitoring SLE disease activity [47,48]. ESR and CRP values are increased proportionally and simultaneously in a subgroup of SLE patients with serositis and/or arthritis [47]. ESR levels greater than $25 \mathrm{~mm} /$ hare strongly associated with SLE disease activity [49]. 


\section{Organ-Specific SLE Biomarkers}

SLE can cause multiple organ damage. Table 2 showed the biomarkers that could assess, monitor, and/or predict organ-specific involvement in patients with SLE, and this information would be helpful for organ-specific precision medicine for patients with SLE.

Table 2. Clinical and immunological biomarkers of organ-specific damage in SLE.

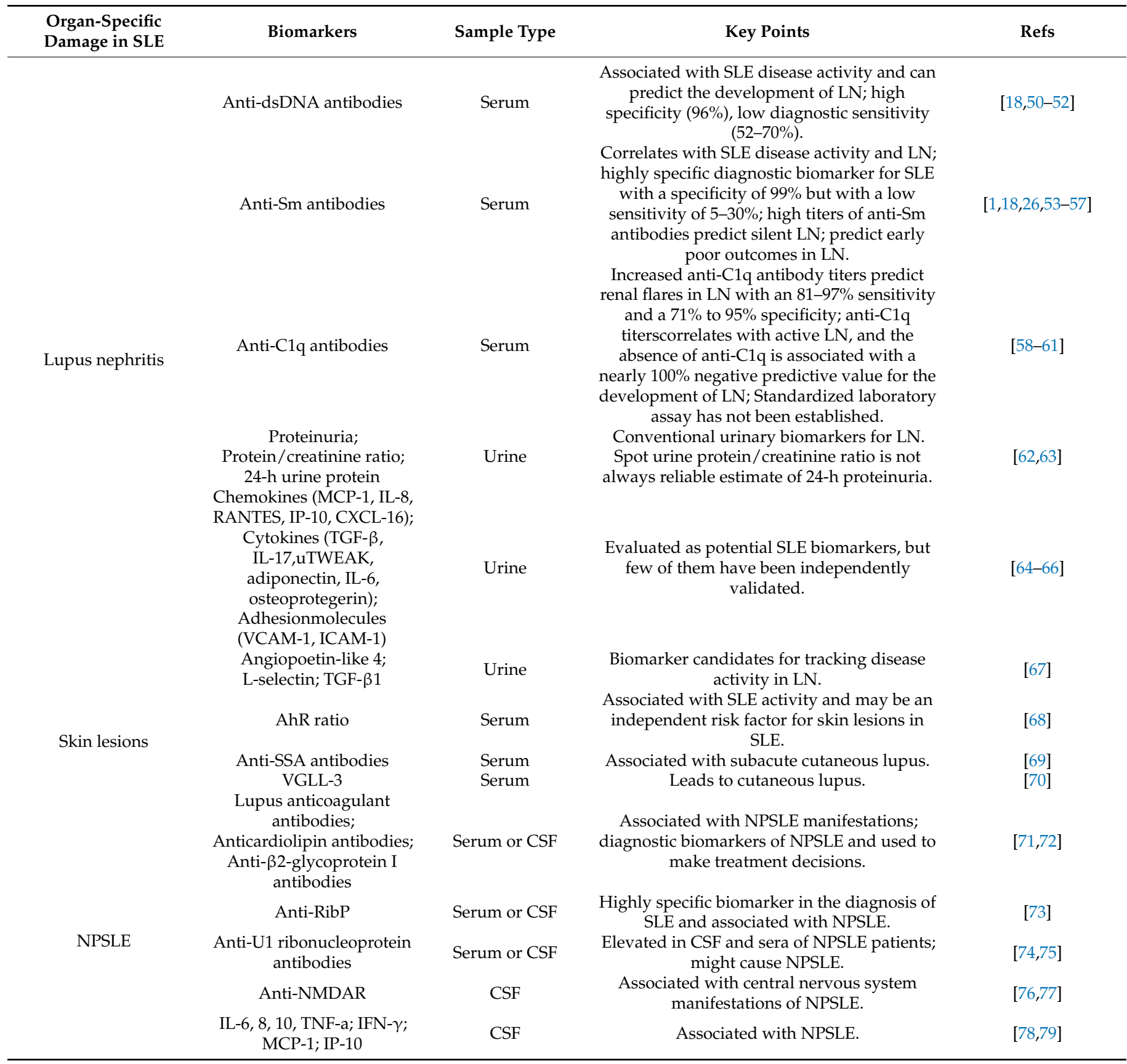


Table 2. Cont.

\begin{tabular}{|c|c|c|c|c|}
\hline $\begin{array}{l}\text { Organ-Specific } \\
\text { Damage in SLE }\end{array}$ & Biomarkers & Sample Type & Key Points & Refs \\
\hline \multirow{5}{*}{ CVD } & LHR; MHR & Serum & $\begin{array}{c}\text { Predicts CVD risk in SLE patients, even at the } \\
\text { onset of disease. }\end{array}$ & [80] \\
\hline & Cardiac troponin $\mathrm{T}$ & Serum & $\begin{array}{l}\text { Independently associated with incident } \\
\text { cardiovascular events in SLE patients. }\end{array}$ & {$[81,82]$} \\
\hline & & & $\begin{array}{l}\text { Key biomarker of accelerated atherosclerosis } \\
\text { in lupus and may serve as a potential } \\
\text { therapeutic biomarker for SLE patients with }\end{array}$ & \\
\hline & Paraoxonase 1 and HDL & Serum & $\begin{array}{c}\text { CVD; early biomarkers of endothelial } \\
\text { damage and premature atherosclerosis in } \\
\text { SLE; therapeutic targets for preventing CVD } \\
\text { in SLE patients. }\end{array}$ & {$[83,84]$} \\
\hline & $\begin{array}{l}\text { IgG-anticardiolipin } \\
\text { antibodies; E-selectin }\end{array}$ & Serum & $\begin{array}{l}\text { Associated with CVD in SLE and correlated } \\
\text { with disease activity. }\end{array}$ & {$[85,86]$} \\
\hline
\end{tabular}

AhR ratio: the ratio of aryl hydrocarbon receptor in Th17 cells to that in Treg; Anti-NMDAR: N-methyl-D-aspartate receptor; CSF: cerebrospinal fluid; CVD: cardiovascular disease; CXCL-16: C-X-C motif chemokine 16; HDL: high-density lipoprotein; ICAM-1: intracellular adhesion molecule1; IL: interleukin; IP-10: interferon[IFN]- $\gamma$-inducible protein 10; LHR: low-density granulocytes-to-high-density lipoprotein cholesterol ratio; MCP-1: monocyte chemoattractant protein-1; MHR: monocyte-to-high-density lipoprotein cholesterol ratio; NPSLE: neuropsychiatric systemic lupus erythematosus; RANTES: regulated upon activation, normal T-cell expressed and secreted; TGF- $\beta$ : transforming growth factor-beta; uTWEAK: urinary tumor necrosis factor [TNF]-like weak inducer of apoptosis; VCAM-1: vascular cellular adhesion molecules 1; VGLL-3: vestigial-like family member 3.

\subsection{Biomarkers in Lupus Nephritis (LN)}

Renal biopsy is the gold standard for diagnosing, classifying, and prognosing LN. However, it cannot be widely employed due to certain disadvantages, including it being an intrinsically invasive procedure, the risk of bleeding, and the possibility of sampling error [87]. Furthermore, a $10 \%$ to $20 \%$ misclassification risk may occur when conducting a fine needle percutaneous renal biopsy because of the possibility of not being able to penetrate the pathological location of renal or pathological error analysis [88]. In addition, serial biopsies cannot be conducted due to the invasive nature and potential complications associated with the procedure $[89,90]$. For these reasons, routine renal biopsy has been considered controversial and a question has been raised about whether it is absolutely required to diagnose $\mathrm{LN}$ [91].

\subsubsection{Serum Anti-dsDNA Antibodies}

Anti-dsDNA antibodies are biomarkers that are associated with SLE disease activity [50,51], and they can predict the development of LN [51]. The level of anti-dsDNA antibodies can fluctuate over time [92] because of their association with SLE disease activity $[38,93]$. They can disappear during treatment and return during a flare, especially in active nephritis [94]. As one of the most characteristic ANA types, anti-dsDNA antibodies have a high specificity (96\%) but low diagnostic sensitivity (52-70\%) for SLE because of their transient appearance [18,52].

IIF using Crithidialuciliae as a substrate and ELISA are the most common assays for anti-dsDNA detection. The level of anti-dsDNA antibodies does not always correlate with active $\mathrm{LN}$, and this makes anti-dsDNA an unreliable biomarker for assessing disease activity [92]. Although anti-dsDNA antibodies can exacerbate LN by being deposited in the kidney or driving cytokine production, the levels of anti-DNA antibodies do not necessarily correlate with active disease [92]. The reasons for anti-dsDNA antibody level variability may be the following: (1) antibody concentration varies with the SLE pathology over time, (2) antibodies may be deposited in renal tissue and not detectable in serum, (3) assays for anti-dsDNA antibodies are not sensitive and specific enough, (4) non-nephritic flares are not always accompanied by anti-dsDNA antibodies [95], and (5) not all subclasses of anti-dsDNA antibodies are pathogenic and associated with disease activity and renal disease $[92,96]$. 


\subsubsection{Serum Anti-SmAntibody}

Presence of anti-Sm antibodies is included in SLE classification criteria and serves as a biomarker for SLE classification $[18,20]$. Anti-Sm antibodies are characteristic of SLE and have not been detected in other rheumatic diseases or in healthy individuals. Anti-Sm antibodies are correlated with SLE disease activity and are a highly specific diagnostic biomarker for SLE with a specificity of $99 \%$ but have a low sensitivity of $5-30 \%[1,18,26,53,54]$. Moreover, anti-Sm antibodies are associated with LN, and their presence in patients with SLE indicates that LN may be acquired in the future $[55,56]$. In addition, high titers of anti-Sm antibodies were identified as predictor of silent LN [57] and may predict early poor outcomes in LN [56].

\subsubsection{Anti-C1q Antibodies}

Hereditary C1q deficiency is strongly associated with SLE [97]. Anti-C1q antibodies result in decreased $\mathrm{C} 1 \mathrm{q}$, which may play a pathogenic role in the development of LN by inhibiting clearance of immune complexes and apoptotic bodies or by depositing immune complexes to the glomerular basement membrane [98,99]. Increased anti-C1q antibody titers predict renal flares in LN with an $81 \%$ to $97 \%$ sensitivity and a $71 \%$ to $95 \%$ specificity $[58,59]$. Moreover, anti-C1q titers are correlated with active $\mathrm{LN}$, and the absence of anti-C1q is associated with a nearly $100 \%$ negative predictive value for the development of LN [60]. These reports suggest that anti-C1q antibodies may serve as a non-invasive biomarker for predicting renal flares. Unfortunately, anti-C1q antibodies have not been included in SLE classification criteria or for the clinical management of SLE because they lack a standardized laboratory assay [61]. In addition, anti-C1q antibodies can be found in other autoimmune diseases, including hypocomplementemic urticarial vasculitis (100\%), Sjögren's syndrome (26\%), rheumatoid arthritis $(19 \%)$, and Stevens-Johnson syndrome $(14 \%)$, and even in apparently healthy individuals $(3-5 \%)[61,98]$.

\subsubsection{Other Urinary Biomarkers}

Urine is an easily and non-invasively obtainable biological sample and it directly reflects pathological changes in kidneys [68]. Hence, urinary biomarkers seem to be more promising than serum biomarkers. Proteinuria, protein/creatinine ratio in spot urine, and 24-h urine protein are conventional urinary biomarkers for LN. However, spot urine protein/creatinine ratio is not always a reliable estimate of 24-h proteinuria [62,63]. Therefore, new urinary biomarkers have been investigated. Various urine protein candidate biomarkers, including chemokines (monocyte chemoattractant protein-1, RANTES, interferon [IFN]- $\gamma$-inducible protein 10 (IP-10), C-X-C motif chemokine 16, and interleukin-8), cytokines (urinary tumor necrosis factor [TNF]-like weak inducer of apoptosis, interleukin17, interleukin-6, adiponectin, transforming growth factor-beta, and osteoprotegerin [64]), growth factors, adhesion molecules (vascular cellular adhesion molecules 1 [65], and intracellular adhesion molecule1 [66]) have been evaluated as potential SLE biomarkers, but few of them have been independently validated. Moreover, urine angiopoetin-like 4, L-selectin, and TGF- $\beta 1$ are biomarker candidates for tracking disease activity in LN [67]. A few points to note regarding urinary biomarkers include that their concentration can vary daily, their measurement could be affected by urinary infections-which should be ruled out, and they may not be specific for a particular disease since most inflammatory diseases share common molecular pathways [68].

\subsection{Biomarkers for Skin Lesions in SLE}

Skin lesions are typical clinical manifestations of SLE, and only a few biomarkers can be used for them. Our previous study reported that the ratio of aryl hydrocarbon receptor in Th17 cells to that in Treg (AhR ratio) is associated with SLE activity, and this ratio may be an independent risk factor for skin lesions in SLE [68]. Moreover, anti-SSA antibodies are associated with subacute cutaneous lupus [69]. The skin-targeted overexpression of 
vestigial-like family member 3 drives a proinflammatory gene expression program that leads to cutaneous lupus [70].

\subsection{Biomarkers in Neuropsychiatric SLE (NPSLE)}

NPSLE is one of the severe complications of lupus, which affects the central and peripheral nervous systems. Biomarkers for NPSLE are obtained from serum or cerebrospinal fluid (CSF) [71]. Antiphospholipid antibodies, including lupus anticoagulant, anticardiolipin, and anti- $\beta 2$-glycoprotein I antibodies, are detected in serum and/or CSF are associated with NPSLE manifestations [71,72]. They are diagnostic biomarkers of NPSLE and used to make treatment decisions [71]. Moreover, the presence of antibodies against $\mathrm{N}$-methyl-D-aspartate receptor (anti-NMDAR) in CSF are associated with central-nervoussystem manifestations of NPSLE, such as an acute confusional state, anxiety disorders, cognitive dysfunctions, mood disorders, and psychosis, and it may distinguish patients with central NPSLE from peripheral NPSLE $[76,77]$. The level of serum anti-NMDAR is higher in patients with NPSLE than in SLE patients without NPSLE [77]. Antibodies against ribosomal proteins (anti-RibP) are a highly specific biomarker for diagnosing SLE and are associated with NPSLE [73]. The variability of anti-RibP test results from different assays and diagnostic platforms is the main challenge for its clinical use [73]. ELISA, immunodiffusion, and immunoblot are the main methods used to detect anti-RibP, and all of them have significant heterogeneity [73].

Increased levels of immunological biomarkers in CSF, such as interleukin-6, interleukin8, interleukin-10, TNF-a, IFN- $\gamma$, monocyte chemoattractant protein-1, and IP-10 were associated with NPSLE [78,79]. Anti-U1 ribonucleoprotein antibodies were elevated in the CSF and sera of NPSLE patients [74], and they might cause NPSLE by inducing neurotoxic inflammatory mediators in the sheath [75].

\subsection{Biomarkers for Cardiovascular Involvement in SLE}

Cardiovascular disease (CVD) is one of the most important complications of SLE, and it is an important factor causing morbidity and mortality. The monocyte-to-high-density lipoprotein cholesterol ratio and low-density granulocytes-to-high-density lipoprotein cholesterol ratio are high in SLE patients with atheromatosis but not in CVD-free patients, and thus they are biomarkers for identifying CVD risk in SLE patients, even at the onset of disease [80]. Moreover, dysfunctional high-density lipoprotein is a key biomarker of accelerated atherosclerosis in lupus and may serve as a potential therapeutic biomarker for SLE patients with CVD [83]. High sensitivity of serum cardiac troponin T was the first identified biomarker that was independently associated with incident cardiovascular events in SLE patients [81,82]. Serum levels of antibodies against paraoxonase 1 and highdensity lipoprotein are potential early biomarkers of endothelial damage and premature atherosclerosis in SLE, and thus they are useful therapeutic targets for preventing CVD in SLE patients [84]. In addition, serum levels of IgG-anticardiolipin antibodies [85] and E-selectin [86] are associated with CVD in lupus and correlated with disease activity.

\section{Omics Approaches in SLE}

Omics approaches provide opportunities for revealing new biomarkers for SLE to track the disease course with greater sensitivity and specificity. Omics, including the transcriptome (mRNA and single-cell), epigenome, genome, and metabolome, have been extensively used to gain insight into SLE [100-102].

\subsection{Transcriptome in SLE}

An integrative analysis of publicly available multi-omics data from the T cells, B cells, and peripheral blood cells of SLE patients demonstrated that 18 transcription factors were significantly enriched in all three types of cells [103]. The most prominent of them were related to type I IFN signaling, such as STAT1 and STAT2, which are two essential components of the IFN-stimulated gene factor 3 complex and can bind to the IFN-stimulated 
response element (ISRE) in the promoters of IFN-stimulated genes (ISGs) [103]. A singlecell transcriptomic analysis of renal stromal cells of LN patients demonstrated that the IFN and fibrosis characteristics of tubule cells might be associated with poorer response to therapy [104]. Using single-cell RNA sequencing, Nehar-Belaid et al. reported that an increased level of ISGs can distinguish cells from children with SLE from cells of healthy controls, and the high levels of ISGs are derived from transcriptionally defined subpopulations within major cell types, including monocytes, $\mathrm{CD}^{+}$and $\mathrm{CD}^{+} \mathrm{T}$ cells, natural killer cells, dendritic cells, B cells, and especially plasma cells. Subpopulations of enriched ISGs and/or monogenic lupus-associated genes can classify SLE activity [105]. Single-cell RNA sequencing was also used to analyze kidney samples from patients with $\mathrm{LN}$, and it was found that local activation of B cells is correlated with an age-associated B-cell signature, and gene expression of immune cells in urine and kidneys was correlated, which indicates that urine might serve as a surrogate for kidney biopsies [106]. Although peripheral blood neutrophils may not be a robust biomarker, they were identified as a risk factor for LN by transcriptomic analyses [107]. Neutrophil-related transcriptome signatures associate with progression to active nephritis [108].

\subsection{Epigenome in SLE}

Epigenetic alterations play a key role in SLE pathogenesis through the dysregulation of gene expression. Epigenetic markers can be influenced by environmental factors. An elegant array of genome-wide approaches was employed to elucidate the epigenetic differences between B cell subsets in patients with SLE from similar subsets derived from healthy control subjects [109]. Epigenetic analyses of B cell subsets from patients with SLE demonstrate that the disease environment can shape the epigenetic networks of B cells [110]. These analyses also reveal the important connections between double-negative and ABC-like B cells [110]. The methylation level of the IFI44L promoter is a highly sensitive and specific diagnostic marker for SLE, and it can separate patients with SLE from healthy persons or patients with other autoimmune diseases [111].

\subsection{Genome in SLE}

Identifying genetic risk loci for SLE susceptibility has been a focus of study for a long time. Genome-wide association studies (GWAS) have been important for generating robust research in the genetics of lupus. Polygenic risk scores (PRS), calculated by GWAS data, showed a 30.3 times higher SLE risk in the patients of the highest decile compared to those in the lowest decile [112]. This suggests that PRS has a very strong impact on SLE susceptibility and may be used as a biomarker for SLE. Moreover, high genetic risk score (GRS) is reported to be associated with an increased risk of organ injury, renal dysfunction, and all-cause mortality in SLE disease [113]. All of these results indicate that assessing the genome may be useful for predicting the risk of getting SLE and its outcomes. Through expression quantitative trait locus (eQTL) analysis, analysis of the association between genetic variants and gene expression levels, we have recently reported that polygenic SLE risks fit closely with the eQTLs of naïve and unswitched memory B cells [114]. In addition, integrin alpha M (ITGAM) was confirmed as a susceptibility gene of LN [115], and the low-frequency risk alleles of the ITGAM gene were identified as risk factors that relate to disease susceptibility and severe manifestations of SLE [116].

\subsection{Metabolome in SLE}

The metabolome is now considered to play a key role in SLE due to developments in mass-spectrometry-based metabolic flux analysis. The fecal metabolomes of 29 SLE patients and 30 healthy controls were analyzed by gas chromatography-mass spectrometry [117]. The results suggest that L-valine, pyrimidine, erucamide, and L-leucine are excellent potential diagnostic biomarkers for SLE, and alterations of fecal metabolites are closely correlated with SLE [117]. Proteomic profiling of kidney tissues from SLE revealed that coronin-1A is a biomarker of $\mathrm{LN}$, and the level of it in serum can distinguish LN patients 
from SLE patients without nephritis with 100\% sensitivity and 100\% specificity [118]. Moreover, granzyme B is increased in the serum and kidneys of patients with SLE, and it is correlated with a poor prognosis of LN [119].

\section{Challenges in Biomarker Discovery}

Biological variability is unavoidable, and it is a great challenge that has been faced in clinical, and especially in 'omics', studies. The variability of assessment is a key factor affecting biomarker studies. For instance, many biomarkers for SLE have not yet demonstrated sufficient sensitivity, specificity, or predictive power for clinical use, and low measurement accuracy and reproducibility also limit their usability. Moreover, the lack of validation cohorts also limits the estimation of any biomarkers that are identified. To improve biomarker studies and measurement accuracy and reproducibility, research should be carefully designed: sample size should be calculated based on sample type and technique employed, parameters should be specific, and appropriate statistical analysis should be conducted [120].

\section{Conclusions and Future Perspectives}

More robust immunological biomarkers are needed to better understand disease progression in individuals with SLE, including non-organ-specific SLE biomarkers and organ-specific SLE biomarkers. Since no single biomarker can be sensitive and specific enough for SLE, multiple biomarkers combined through mathematical models may be a good idea for assessing SLE. Moreover, advanced computational methods are required to analyze large datasets and discover novel biomarkers.

Author Contributions: H.Y. and Y.N. conceived the presented idea; H.Y. drafted the manuscript. Y.N. and K.F. professionally edited the manuscript. All authors have read and agreed to the published version of the manuscript.

Funding: This work was supported by grants from the National Natural Science Foundation of China (81960388), the Longyuan Youth Innovation and Entrepreneurship Talents (grant number No. 9, 2020, Organization Department of Gansu Province), the Natural Science Foundation of Gansu Province (grant number 20JR5RA367), the Science and Technology Plan Project of Chengguan District Lanzhou City (grant number 2020-2-11-3), and the GSK Japan Research Grant 2020.

Institutional Review Board Statement: Not applicable.

Informed Consent Statement: Not applicable.

Conflicts of Interest: Y.H. declare no conflict of interest. Y.N. received financial support or fees from BMS, Chugai, Kissei, GlaxoSmithKline, and Pfizer. K. Fujio received grants, consulting fees, speaking fees, and/or honoraria from Takeda, BMS, Mitsubishi Tanabe, Asahi Kasei, Sanofi, Eli Lilly, Daiichi Sankyo, Ono, Janssen, AbbVie, Astellas, Eisai, Pfizer, Chugai, Novartis, UCB, Tsumura, Taisho Toyama, Nihon Kayaku, and Ayumi.

\section{References}

1. Kiriakidou, M.; Ching, C. Systemic Lupus Erythematosus. Ann. Intern. Med. 2020, 172, ITC81-ITC96. [CrossRef] [PubMed]

2. Tsokos, G.C. Systemic lupus erythematosus. N. Engl. J. Med. 2011, 365, 2110-2121. [CrossRef]

3. Gergianaki, I.; Fanouriakis, A.; Repa, A.; Tzanakakis, M.; Adamichou, C.; Pompieri, A.; Spirou, G.; Bertsias, A.; Kabouraki, E.; Tzanakis, I.; et al. Epidemiology and burden of systemic lupus erythematosus in a Southern European population: Data from the community-based lupus registry of Crete, Greece. Ann. Rheum. Dis. 2017, 76, 1992-2000. [CrossRef] [PubMed]

4. Rees, F.; Doherty, M.; Grainge, M.; Lanyon, P.; Zhang, W. The worldwide incidence and prevalence of systemic lupus erythematosus: A systematic review of epidemiological studies. Rheumatology 2017, 56, 1945-1961. [CrossRef]

5. Bertsias, G.; Karampli, E.; Sidiropoulos, P.; Gergianaki, I.; Drosos, A.; Sakkas, L.; Garyfallos, A.; Tzioufas, A.; Vassilopoulos, D.; Tsalapaki, C.; et al. Clinical and financial burden of active lupus in Greece: A nationwide study. Lupus 2016, 25, 1385-1394. [CrossRef] [PubMed]

6. Murimi-Worstell, I.B.; Lin, D.H.; Kan, H.; Tierce, J.; Wang, X.; Nab, H.; Desta, B.; Alexander, G.C.; Hammond, E.R. Healthcare Utilization and Costs of Systemic Lupus Erythematosus by Disease Severity in the United States. J. Rheumatol. 2021, 48, 385-393. [CrossRef] [PubMed] 
7. Doria, A.; Amoura, Z.; Cervera, R.; Khamastha, M.A.; Schneider, M.; Richter, J.; Guillemin, F.; Kobelt, G.; Maurel, F.; Garofano, A.; et al. Annual direct medical cost of active systemic lupus erythematosus in five European countries. Ann. Rheum. Dis. 2014, 73, 154-160. [CrossRef]

8. Szefler, S.J.; Wenzel, S.; Brown, R.; Erzurum, S.C.; Fahy, J.V.; Hamilton, R.G.; Hunt, J.F.; Kita, H.; Liu, A.H.; Panettieri, R.A., Jr.; et al. Asthma outcomes: Biomarkers. J. Allergy Clin. Immunol. 2012, 129, S9-S23. [CrossRef] [PubMed]

9. González, L.A.; Ugarte-Gil, M.F.; Alarcón, G.S. Systemic lupus erythematosus: The search for the ideal biomarker. Lupus 2020, 961203320979051. [CrossRef]

10. Bertolo, M.; Baumgart, S.; Durek, P.; Peddinghaus, A.; Mei, H.; Rose, T.; Enghard, P.; Grützkau, A. Deep Phenotyping of Urinary Leukocytes by Mass Cytometry Reveals a Leukocyte Signature for Early and Non-Invasive Prediction of Response to Treatment in Active Lupus Nephritis. Front. Immunol. 2020, 11, 256. [CrossRef]

11. Narendra, D.; Blixt, J.; Hanania, N. Immunological biomarkers in severe asthma. Semin. Immunol. 2019, 46, 101332. [CrossRef] [PubMed]

12. Liu, C.-C.; Ahearn, J.M. The search for lupus biomarkers. Best Pract. Res. Clin. Rheumatol. 2009, 23, 507-523. [CrossRef] [PubMed]

13. Illei, G.G.; Tackey, E.; Lapteva, L.; Lipsky, P.E. Biomarkers in systemic lupus erythematosus. I. General overview of biomarkers and their applicability. Arthritis Rheum. 2004, 50, 1709-1720. [CrossRef] [PubMed]

14. Wu, H.; Zeng, J.; Yin, J.; Peng, Q.; Zhao, M.; Lu, Q. Organ-specific biomarkers in lupus. Autoimmun. Rev. 2017, 16, 391-397. [CrossRef]

15. Liu, C.-C.; Kao, A.H.; Manzi, S.; Ahearn, J.M. Biomarkers in systemic lupus erythematosus: Challenges and prospects for the future. Ther. Adv. Musculoskelet. Dis. 2013, 5, 210-233. [CrossRef]

16. Tan, E.M.; Cohen, A.S.; Fries, J.F.; Masi, A.T.; McShane, D.J.; Rothfield, N.F.; Schaller, J.G.; Talal, N.; Winchester, R.J. The 1982 revised criteria for the classification of systemic lupus erythematosus. Arthritis Rheum. 1982, 25, 1271-1277. [CrossRef]

17. Hochberg, M.C. Updating the American College of Rheumatology revised criteria for the classification of systemic lupus erythematosus. Arthritis Rheum. 1997, 40, 1725. [CrossRef] [PubMed]

18. Petri, M.; Orbai, A.-M.; Alarcón, G.S.; Gordon, C.; Merrill, J.T.; Fortin, P.R.; Bruce, I.N.; Isenberg, D.; Wallace, D.J.; Nived, O.; et al. Derivation and validation of the Systemic Lupus International Collaborating Clinics classification criteria for systemic lupus erythematosus. Arthritis Rheum. 2012, 64, 2677-2686.

19. Aringer, M.; Dörner, T.; Leuchten, N.; Johnson, S. Toward new criteria for systemic lupus erythematosus-a standpoint. Lupus 2016, 25, 805-811. [CrossRef]

20. Aringer, M.; Costenbader, K.; Daikh, D.; Brinks, R.; Mosca, M.; Ramsey-Goldman, R.; Smolen, J.S.; Wofsy, D.; Boumpas, D.T.; Kamen, D.L.; et al. 2019 European League Against Rheumatism/American College of Rheumatology Classification Criteria for Systemic Lupus Erythematosus. Arthritis Rheumatol. 2019, 71, 1400-1412. [CrossRef]

21. Adamichou, C.; Nikolopoulos, D.; Genitsaridi, I.; Bortoluzzi, A.; Fanouriakis, A.; Papastefanakis, E.; Kalogiannaki, E.; Gergianaki, I.; Sidiropoulos, P.; Boumpas, D.T.; et al. In an early SLE cohort the ACR-1997, SLICC-2012 and EULAR/ACR-2019 criteria classify non-overlapping groups of patients: Use of all three criteria ensures optimal capture for clinical studies while their modification earlier classification and treatment. Ann. Rheum. Dis. 2020, 79, 232-241. [CrossRef]

22. Sacre, K.; Delaval, L.; Dossier, A.; Alexandra, J.-F.; Berleur, M.; Chauveheid, M.-P.; Ducrocq, G.; Goulenok, T.; van Gysel, D.; Rouzaud, D.; et al. New 2019 SLE EULAR/ACR classification criteria are valid for identifying patients with SLE among patients admitted for pericardial effusion. Ann. Rheum. Dis. 2019. [CrossRef]

23. Nikolopoulos, D.; Kostopoulou, M.; Pieta, A.; Karageorgas, T.; Tseronis, D.; Chavatza, K.; Flouda, S.; Rapsomaniki, P.; Banos, A.; Kremasmenou, E.; et al. Evolving phenotype of systemic lupus erythematosus in Caucasians: Low incidence of lupus nephritis, high burden of neuropsychiatric disease and increased rates of late-onset lupus in the 'Attikon' cohort. Lupus 2020, 29 , 514-522. [CrossRef]

24. Larosa, M.; Iaccarino, L.; Gatto, M.; Punzi, L.; Doria, A. Advances in the diagnosis and classification of systemic lupus erythematosus. Expert Rev. Clin. Immunol. 2016, 12, 1309-1320. [CrossRef] [PubMed]

25. Damoiseaux, J.; Andrade, L.E.C.; Carballo, O.G.; Conrad, K.; Francescantonio, P.L.C.; Fritzler, M.J.; Garcia de la Torre, I.; Herold, M.; Klotz, W.; Cruvinel, W.M.; et al. Clinical relevance of HEp-2 indirect immunofluorescent patterns: The International Consensus on ANA patterns (ICAP) perspective. Ann. Rheum. Dis. 2019, 78, 879-889. [CrossRef]

26. Olsen, N.J.; Karp, D.R. Autoantibodies and SLE: The threshold for disease. Nat. Rev. Rheumatol. 2014, 10, 181-186. [CrossRef]

27. Meroni, P.L.; Schur, P.H. ANA screening: An old test with new recommendations. Ann. Rheum. Dis. 2010, 69, 1420-1422. [CrossRef] [PubMed]

28. Pisetsky, D.S. Evolving story of autoantibodies in systemic lupus erythematosus. J. Autoimmun. 2020, 110, 102356. [CrossRef]

29. Pisetsky, D.S. Antinuclear antibody testing-Misunderstood or misbegotten? Nat. Rev. Rheumatol. 2017, 13, 495-502. [CrossRef]

30. Emlen, W.; O'Neill, L. Clinical significance of antinuclear antibodies: Comparison of detection with immunofluorescence and enzyme-linked immunosorbent assays. Arthritis Rheum. 1997, 40, 1612-1618. [CrossRef] [PubMed]

31. Oke, V.; Wahren-Herlenius, M. Cutaneous lupus erythematosus: Clinical aspects and molecular pathogenesis. J. Intern. Med. 2013, 273, 544-554. [CrossRef]

32. Sjöwall, C.; Sturm, M.; Dahle, C.; Bengtsson, A.A.; Jönsen, A.; Sturfelt, G.; Skogh, T. Abnormal antinuclear antibody titers are less common than generally assumed in established cases of systemic lupus erythematosus. J. Rheumatol. 2008, 35, 1994-2000. 
33. Choi, M.Y.; Clarke, A.E.; St Pierre, Y.; Hanly, J.G.; Urowitz, M.B.; Romero-Diaz, J.; Gordon, C.; Bae, S.-C.; Bernatsky, S.; Wallace, D.J.; et al. Antinuclear Antibody-Negative Systemic Lupus Erythematosus in an International Inception Cohort. Arthritis Care Res. 2019, 71, 893-902. [CrossRef]

34. Pisetsky, D.S.; Rovin, B.H.; Lipsky, P.E. New Perspectives in Rheumatology: Biomarkers as Entry Criteria for Clinical Trials of New Therapies for Systemic Lupus Erythematosus: The Example of Antinuclear Antibodies and Anti-DNA. Arthritis Rheumatol. 2017, 69, 487-493. [CrossRef] [PubMed]

35. Furie, R.; Petri, M.; Zamani, O.; Cervera, R.; Wallace, D.J.; Tegzová, D.; Sanchez-Guerrero, J.; Schwarting, A.; Merrill, J.T.; Chatham, W.W.; et al. A phase III, randomized, placebo-controlled study of belimumab, a monoclonal antibody that inhibits B lymphocyte stimulator, in patients with systemic lupus erythematosus. Arthritis Rheum. 2011, 63, 3918-3930. [CrossRef] [PubMed]

36. Pisetsky, D.S.; Spencer, D.M.; Lipsky, P.E.; Rovin, B.H. Assay variation in the detection of antinuclear antibodies in the sera of patients with established SLE. Ann. Rheum. Dis. 2018, 77, 911-913. [CrossRef] [PubMed]

37. Olsen, N.J.; Choi, M.Y.; Fritzler, M.J. Emerging technologies in autoantibody testing for rheumatic diseases. Arthrit. Res. Ther. 2017, 19, 172. [CrossRef]

38. Pisetsky, D.S.; Lipsky, P.E. New insights into the role of antinuclear antibodies in systemic lupus erythematosus. Nat. Rev. Rheumatol. 2020, 16, 565-579. [CrossRef]

39. Pisetsky, D.S.; Bossuyt, X.; Meroni, P.L. ANA as an entry criterion for the classification of SLE. Autoimmun. Rev. 2019, 18, 102400. [CrossRef]

40. Leffler, J.; Bengtsson, A.A.; Blom, A.M. The complement system in systemic lupus erythematosus: An update. Ann. Rheum. Dis. 2014, 73, 1601-1606. [CrossRef] [PubMed]

41. Trouw, L.A.; Pickering, M.C.; Blom, A.M. The complement system as a potential therapeutic target in rheumatic disease. Nat. Rev. Rheumatol. 2017, 13, 538-547. [CrossRef] [PubMed]

42. Li, H.; Lin, S.; Yang, S.; Chen, L.; Zheng, X. Diagnostic value of serum complement C3 and C4 levels in Chinese patients with systemic lupus erythematosus. Clin. Rheumatol. 2015, 34, 471-477. [CrossRef] [PubMed]

43. Petri, M.A.; van Vollenhoven, R.F.; Buyon, J.; Levy, R.A.; Navarra, S.V.; Cervera, R.; Zhong, Z.J.; Freimuth, W.W. Baseline predictors of systemic lupus erythematosus flares: Data from the combined placebo groups in the phase III belimumab trials. Arthritis Rheum. 2013, 65, 2143-2153. [CrossRef]

44. Ho, A.; Barr, S.G.; Magder, L.S.; Petri, M. A decrease in complement is associated with increased renal and hematologic activity in patients with systemic lupus erythematosus. Arthritis Rheum. 2001, 44, 2350-2357. [CrossRef]

45. Gómez-Puerta, J.A.; Burlingame, R.W.; Cervera, R. Anti-chromatin (anti-nucleosome) antibodies: Diagnostic and clinical value. Autoimmun. Rev. 2008, 7, 606-611. [CrossRef] [PubMed]

46. Bizzaro, N.; Villalta, D.; Giavarina, D.; Tozzoli, R. Are anti-nucleosome antibodies a better diagnostic marker than anti-dsDNA antibodies for systemic lupus erythematosus? A systematic review and a study of metanalysis. Autoimmun. Rev. 2012, 12, 97-106. [CrossRef]

47. Dima, A.; Opris, D.; Jurcut, C.; Baicus, C. Is there still a place for erythrocyte sedimentation rate and C-reactive protein in systemic lupus erythematosus? Lupus 2016, 25, 1173-1179. [CrossRef]

48. Bertoli, A.M.; Vilá, L.M.; Reveille, J.D.; Alarcón, G.S. Systemic lupus erythematosus in a multiethnic US cohort (LUMINA): LXI Value of C-reactive protein as a marker of disease activity and damage. J. Rheumatol. 2008, 35, 2355-2358. [CrossRef] [PubMed]

49. Stojan, G.; Fang, H.; Magder, L.; Petri, M. Erythrocyte sedimentation rate is a predictor of renal and overall SLE disease activity. Lupus 2013, 22, 827-834. [CrossRef]

50. Merrill, J.T.; Petri, M.A.; Buyon, J.; Ramsey-Goldman, R.; Kalunian, K.; Putterman, C.; Conklin, J.; Furie, R.A.; Dervieux, T. Erythrocyte-bound C4d in combination with complement and autoantibody status for the monitoring of SLE. Lupus Sci. Med. 2018, 5, e000263. [CrossRef] [PubMed]

51. Alarcón, G.S.; Calvo-Alén, J.; McGwin, G.; Uribe, A.G.; Toloza, S.M.A.; Roseman, J.M.; Fernández, M.; Fessler, B.J.; Vilá, L.M.; Ahn, C.; et al. Systemic lupus erythematosus in a multiethnic cohort: LUMINA XXXV. Predictive factors of high disease activity over time. Ann. Rheum. Dis. 2006, 65, 1168-1174. [CrossRef] [PubMed]

52. Kavanaugh, A.F.; Solomon, D.H. Guidelines for immunologic laboratory testing in the rheumatic diseases: Anti-DNA antibody tests. Arthritis Rheum. 2002, 47, 546-555. [CrossRef] [PubMed]

53. Amezcua-Guerra, L.M.; Higuera-Ortiz, V.; Arteaga-García, U.; Gallegos-Nava, S.; Hübbe-Tena, C. Performance of the 2012 Systemic Lupus International Collaborating Clinics and the 1997 American College of Rheumatology classification criteria for systemic lupus erythematosus in a real-life scenario. Arthritis Care Res. 2015, 67, 437-441. [CrossRef] [PubMed]

54. Frodlund, M.; Wetterö, J.; Dahle, C.; Dahlström, Ö.; Skogh, T.; Rönnelid, J.; Sjöwall, C. Longitudinal anti-nuclear antibody (ANA) seroconversion in systemic lupus erythematosus: A prospective study of Swedish cases with recent-onset disease. Clin. Exp. Immunol. 2020, 199, 245-254. [CrossRef]

55. Kwon, O.C.; Lee, J.S.; Ghang, B.; Kim, Y.G.; Lee, C.K.; Yoo, B.; Hong, S. Predicting eventual development of lupus nephritis at the time of diagnosis of systemic lupus erythematosus. Semin. Arthritis Rheum. 2018, 48, 462-466. [CrossRef]

56. Ahn, S.S.; Yoo, B.W.; Song, J.J.; Park, Y.B.; Lee, S.K.; Lee, S.W. Anti-Sm is associated with the early poor outcome of lupus nephritis. Int. J. Rheum. Dis. 2016, 19, 897-902. [CrossRef] 
57. Ishizaki, J.; Saito, K.; Nawata, M.; Mizuno, Y.; Tokunaga, M.; Sawamukai, N.; Tamura, M.; Hirata, S.; Yamaoka, K.; Hasegawa, H.; et al. Low complements and high titre of anti-Sm antibody as predictors of histopathologically proven silent lupus nephritis without abnormal urinalysis in patients with systemic lupus erythematosus. Rheumatology 2015, 54, 405-412. [CrossRef] [PubMed]

58. Moroni, G.; Radice, A.; Giammarresi, G.; Quaglini, S.; Gallelli, B.; Leoni, A.; Li Vecchi, M.; Vecchi, M.L.; Messa, P.; Sinico, R.A. Are laboratory tests useful for monitoring the activity of lupus nephritis? A 6-year prospective study in a cohort of 228 patients with lupus nephritis. Ann. Rheum. Dis. 2009, 68, 234-237. [CrossRef] [PubMed]

59. Matrat, A.; Veysseyre-Balter, C.; Trolliet, P.; Villar, E.; Dijoud, F.; Bienvenu, J.; Fabien, N. Simultaneous detection of anti-C1q and anti-double stranded DNA autoantibodies in lupus nephritis: Predictive value for renal flares. Lupus 2011, 20, 28-34. [CrossRef] [PubMed]

60. Trendelenburg, M.; Marfurt, J.; Gerber, I.; Tyndall, A.; Schifferli, J.A. Lack of occurrence of severe lupus nephritis among anti-C1q autoantibody-negative patients. Arthritis Rheum. 1999, 42, 187-188. [CrossRef]

61. Orbai, A.M.; Truedsson, L.; Sturfelt, G.; Nived, O.; Fang, H.; Alarcón, G.S.; Gordon, C.; Merrill, J.; Fortin, P.R.; Bruce, I.N.; et al. Anti-C1q antibodies in systemic lupus erythematosus. Lupus 2015, 24, 42-49. [CrossRef] [PubMed]

62. Zhang, Q.; Sun, L.; Jin, L. Spot urine protein/creatinine ratio is unreliable estimate of 24 h proteinuria in lupus nephritis when the histological scores of activity index are higher. Lupus 2015, 24, 943-947. [CrossRef]

63. Guedes Marques, M.; Cotovio, P.; Ferrer, F.; Silva, C.; Botelho, C.; Lopes, K.; Maia, P.; Carreira, A.; Campos, M. Random spot urine protein/creatinine ratio: A reliable method for monitoring lupus nephritis? Clin. Kidney J. 2013, 6, 590-594. [CrossRef]

64. Schwartz, N.; Rubinstein, T.; Burkly, L.C.; Collins, C.E.; Blanco, I.; Su, L.; Hojaili, B.; Mackay, M.; Aranow, C.; Stohl, W.; et al Urinary TWEAK as a biomarker of lupus nephritis: A multicenter cohort study. Arthrit. Res. Ther. 2009, 11, R143. [CrossRef] [PubMed]

65. Howe, H.S.; Kong, K.O.; Thong, B.Y.H.; Law, W.G.; Chia, F.L.A.; Lian, T.Y.; Lau, T.C.; Chng, H.H.; Leung, B.P.L. Urine sVCAM-1 and sICAM-1 levels are elevated in lupus nephritis. Int. J. Rheum. Dis. 2012, 15, 13-16. [CrossRef]

66. Guo Liu, R.-N.; Cheng, Q.-Y.; Zhou, H.-Y.; Li, B.-Z.; Ye, D.-Q. Elevated Blood and Urinary ICAM-1 is a Biomarker for Systemic Lupus Erythematosus: A Systematic Review and Meta-Analysis. Immunol. Investig. 2020, 49, 15-31. [CrossRef] [PubMed]

67. Vanarsa, K.; Soomro, S.; Zhang, T.; Strachan, B.; Pedroza, C.; Nidhi, M.; Cicalese, P.; Gidley, C.; Dasari, S.; Mohan, S.; et al. Quantitative planar array screen of 1000 proteins uncovers novel urinary protein biomarkers of lupus nephritis. Ann. Rheum. Dis. 2020, 79, 1349-1361. [CrossRef]

68. Yu, H.; Jiang, L.; Liu, R.; Yang, A.; Yang, X.; Wang, L.; Zhang, W.; Che, T. Association between the ratio of aryl hydrocarbon receptor (AhR) in Th17 cells to AhR in Treg cells and SLE skin lesions. Int. Immunopharmacol. 2019, 69, 257-262. [CrossRef] [PubMed]

69. Schulte-Pelkum, J.; Fritzler, M.; Mahler, M. Latest update on the Ro/SS-A autoantibody system. Autoimmun. Rev. 2009, 8, 632-637. [CrossRef] [PubMed]

70. Billi, A.C.; Gharaee-Kermani, M.; Fullmer, J.; Tsoi, L.C.; Hill, B.D.; Gruszka, D.; Ludwig, J.; Xing, X.; Estadt, S.; Wolf, S.J.; et al. The female-biased factor VGLL3 drives cutaneous and systemic autoimmunity. JCI Insight 2019, 4, e127291. [CrossRef] [PubMed]

71. Jeltsch-David, H.; Muller, S. Neuropsychiatric systemic lupus erythematosus: Pathogenesis and biomarkers. Nat. Rev. Neurol. 2014, 10, 579-596. [CrossRef] [PubMed]

72. Ho, R.C.; Thiaghu, C.; Ong, H.; Lu, Y.; Ho, C.S.; Tam, W.W.; Zhang, M.W. A meta-analysis of serum and cerebrospinal fluid autoantibodies in neuropsychiatric systemic lupus erythematosus. Autoimmun. Rev. 2016, 15, 124-138. [CrossRef]

73. Choi, M.Y.; FitzPatrick, R.D.; Buhler, K.; Mahler, M.; Fritzler, M.J. A review and meta-analysis of anti-ribosomal P autoantibodies in systemic lupus erythematosus. Autoimmun. Rev. 2020, 19, 102463. [CrossRef] [PubMed]

74. Hirohata, S.; Sakuma, Y.; Yanagida, T.; Yoshio, T. Association of cerebrospinal fluid anti-Sm antibodies with acute confusional state in systemic lupus erythematosus. Arthrit. Res. Ther. 2014, 16, 450. [CrossRef]

75. Fujii, T. Direct and indirect pathogenic roles of autoantibodies in systemic autoimmune diseases. Allergol. Int. 2014, 63, 515-522. [CrossRef] [PubMed]

76. Arinuma, Y.; Yanagida, T.; Hirohata, S. Association of cerebrospinal fluid anti-NR2 glutamate receptor antibodies with diffuse neuropsychiatric systemic lupus erythematosus. Arthritis Rheum. 2008, 58, 1130-1135. [CrossRef]

77. Fragoso-Loyo, H.; Cabiedes, J.; Orozco-Narváez, A.; Dávila-Maldonado, L.; Atisha-Fregoso, Y.; Diamond, B.; Llorente, L.; Sánchez-Guerrero, J. Serum and cerebrospinal fluid autoantibodies in patients with neuropsychiatric lupus erythematosus. Implications for diagnosis and pathogenesis. PLoS ONE 2008, 3, e3347. [CrossRef] [PubMed]

78. Bertsias, G.K.; Boumpas, D.T. Pathogenesis, diagnosis and management of neuropsychiatric SLE manifestations. Nat. Rev. Rheumatol. 2010, 6, 358-367. [CrossRef]

79. Fragoso-Loyo, H.; Richaud-Patin, Y.; Orozco-Narváez, A.; Dávila-Maldonado, L.; Atisha-Fregoso, Y.; Llorente, L.; SánchezGuerrero, J. Interleukin-6 and chemokines in the neuropsychiatric manifestations of systemic lupus erythematosus. Arthritis Rheum. 2007, 56, 1242-1250. [CrossRef] [PubMed]

80. López, P.; Rodríguez-Carrio, J.; Martínez-Zapico, A.; Pérez-Álvarez, Á.I.; Suárez-Díaz, S.; Mozo, L.; Benavente, L.; CaminalMontero, L.; Suárez, A. Low-density granulocytes and monocytes as biomarkers of cardiovascular risk in systemic lupus erythematosus. Rheumatology 2020, 59, 1752-1764. [CrossRef] 
81. Chezel, J.; Costedoat-Chalumeau, N.; Laouénan, C.; Rouzaud, D.; Chenevier-Gobeaux, C.; Le Guern, V.; Mathian, A.; Belhadi, D.; de Almeida Chaves, S.; Duhaut, P.; et al. Highly sensitive serum cardiac troponin T and cardiovascular events in patients with systemic lupus erythematosus (TROPOPLUS study). Rheumatology 2021, 60, 1210-1215. [CrossRef]

82. Winau, L.; Hinojar Baydes, R.; Braner, A.; Drott, U.; Burkhardt, H.; Sangle, S.; D'Cruz, D.P.; Carr-White, G.; Marber, M.; Schnoes, K.; et al. High-sensitive troponin is associated with subclinical imaging biosignature of inflammatory cardiovascular involvement in systemic lupus erythematosus. Ann. Rheum. Dis. 2018, 77, 1590-1598. [CrossRef] [PubMed]

83. Kim, S.Y.; Yu, M.; Morin, E.E.; Kang, J.; Kaplan, M.J.; Schwendeman, A. High-Density Lipoprotein in Lupus: Disease Biomarkers and Potential Therapeutic Strategy. Arthritis Rheumatol. 2020, 72, 20-30. [CrossRef]

84. López, P.; Rodríguez-Carrio, J.; Martínez-Zapico, A.; Pérez-Álvarez, Á.I.; López-Mejías, R.; Benavente, L.; Mozo, L.; CaminalMontero, L.; González-Gay, M.A.; Suárez, A. Serum Levels of Anti-PON1 and Anti-HDL Antibodies as Potential Biomarkers of Premature Atherosclerosis in Systemic Lupus Erythematosus. Thromb. Haemost. 2017, 117, 2194-2206. [CrossRef] [PubMed]

85. Domingues, V.; Magder, L.S.; Petri, M. Assessment of the independent associations of IgG, IgM and IgA isotypes of anticardiolipin with thrombosis in SLE. Lupus Sci. Med. 2016, 3, e000107. [CrossRef]

86. Skeoch, S.; Haque, S.; Pemberton, P.; Bruce, I.N. Cell adhesion molecules as potential biomarkers of nephritis, damage and accelerated atherosclerosis in patients with SLE. Lupus 2014, 23, 819-824. [CrossRef]

87. Stanley, S.; Mok, C.C.; Vanarsa, K.; Habazi, D.; Li, J.; Pedroza, C.; Saxena, R.; Mohan, C. Identification of Low-Abundance Urinary Biomarkers in Lupus Nephritis Using Electrochemiluminescence Immunoassays. Arthritis Rheumatol. 2019, 71, 744-755. [CrossRef]

88. Rovin, B.H.; Parikh, S.V.; Alvarado, A. The kidney biopsy in lupus nephritis: Is it still relevant? Rheum. Dis. Clin. N. Am. 2014, 40, 537-552. [CrossRef]

89. Caster, D.J.; Merchant, M.L.; Klein, J.B.; Powell, D.W. Precision medicine in lupus nephritis: Can biomarkers get us there? Transl. Res. 2018, 201, 26-39. [CrossRef]

90. Aragón, C.C.; Tafúr, R.-A.; Suárez-Avellaneda, A.; Martínez, M.T.; Salas, A.L.; Tobón, G.J. Urinary biomarkers in lupus nephritis. J. Transl. Autoimmun. 2020, 3, 100042. [CrossRef] [PubMed]

91. Giannico, G.; Fogo, A.B. Lupus nephritis: Is the kidney biopsy currently necessary in the management of lupus nephritis? Clin. J. Am. Soc. Nephrol. CJASN 2013, 8, 138-145. [CrossRef]

92. Pisetsky, D.S. Anti-DNA antibodies-quintessential biomarkers of SLE. Nat. Rev. Rheumatol. 2016, 12, 102-110. [CrossRef] [PubMed]

93. Bombardier, C.; Gladman, D.D.; Urowitz, M.B.; Caron, D.; Chang, C.H. Derivation of the SLEDAI. A disease activity index for lupus patients. The Committee on Prognosis Studies in SLE. Arthritis Rheum. 1992, 35, 630-640. [CrossRef] [PubMed]

94. ter Borg, E.J.; Horst, G.; Hummel, E.J.; Limburg, P.C.; Kallenberg, C.G. Measurement of increases in anti-double-stranded DNA antibody levels as a predictor of disease exacerbation in systemic lupus erythematosus. A long-term, prospective study. Arthritis Rheum. 1990, 33, 634-643. [CrossRef]

95. de Leeuw, K.; Bungener, L.; Roozendaal, C.; Bootsma, H.; Stegeman, C.A. Auto-antibodies to double-stranded DNA as biomarker in systemic lupus erythematosus: Comparison of different assays during quiescent and active disease. Rheumatology 2017, 56, 698-703. [CrossRef]

96. Steiman, A.J.; Urowitz, M.B.; Ibañez, D.; Li, T.T.; Gladman, D.D.; Wither, J. Anti-dsDNA and Antichromatin Antibody Isotypes in Serologically Active Clinically Quiescent Systemic Lupus Erythematosus. J. Rheumatol. 2015, 42, 810-816. [CrossRef]

97. Schejbel, L.; Skattum, L.; Hagelberg, S.; Åhlin, A.; Schiller, B.; Berg, S.; Genel, F.; Truedsson, L.; Garred, P. Molecular basis of hereditary C1q deficiency-revisited: Identification of several novel disease-causing mutations. Genes Immun. 2011, 12, 626-634. [CrossRef]

98. Stojan, G.; Petri, M. Anti-C1q in systemic lupus erythematosus. Lupus 2016, 25, 873-877. [CrossRef] [PubMed]

99. Sinico, R.A.; Rimoldi, L.; Radice, A.; Bianchi, L.; Gallelli, B.; Moroni, G. Anti-C1q autoantibodies in lupus nephritis. Ann. N. Y. Acad. Sci. 2009, 1173, 47-51. [CrossRef] [PubMed]

100. Teruel, M.; Chamberlain, C.; Alarcón-Riquelme, M.E. Omics studies: Their use in diagnosis and reclassification of SLE and other systemic autoimmune diseases. Rheumatolog 2017, 56, i78-i87. [CrossRef] [PubMed]

101. Mathieu, C.; Lahesmaa, R.; Bonifacio, E.; Achenbach, P.; Tree, T. Immunological biomarkers for the development and progression of type 1 diabetes. Diabetologia 2018, 61, 2252-2258. [CrossRef]

102. Arriens, C.; Mohan, C. Systemic lupus erythematosus diagnostics in the 'omics' era. Int. J. Clin. Rheumtol. 2013, 8, 671-687. [CrossRef]

103. Wang, T.-Y.; Wang, Y.-F.; Zhang, Y.; Shen, J.J.; Guo, M.; Yang, J.; Lau, Y.L.; Yang, W. Identification of Regulatory Modules That Stratify Lupus Disease Mechanism through Integrating Multi-Omics Data. Mol. Ther. Nucleic Acids 2020, 19, 318-329. [CrossRef]

104. Der, E.; Suryawanshi, H.; Morozov, P.; Kustagi, M.; Goilav, B.; Ranabothu, S.; Izmirly, P.; Clancy, R.; Belmont, H.M.; Koenigsberg, M.; et al. Tubular cell and keratinocyte single-cell transcriptomics applied to lupus nephritis reveal type I IFN and fibrosis relevant pathways. Nat. Immunol. 2019, 20, 915-927. [CrossRef] [PubMed]

105. Nehar-Belaid, D.; Hong, S.; Marches, R.; Chen, G.; Bolisetty, M.; Baisch, J.; Walters, L.; Punaro, M.; Rossi, R.J.; Chung, C.-H.; et al. Mapping systemic lupus erythematosus heterogeneity at the single-cell level. Nat. Immunol. 2020, 21, 1094-1106. [CrossRef] [PubMed] 
106. Arazi, A.; Rao, D.A.; Berthier, C.C.; Davidson, A.; Liu, Y.; Hoover, P.J.; Chicoine, A.; Eisenhaure, T.M.; Jonsson, A.H.; Li, S.; et al. The immune cell landscape in kidneys of patients with lupus nephritis. Nat. Immunol. 2019, 20, 902-914. [CrossRef] [PubMed]

107. Jourde-Chiche, N.; Whalen, E.; Gondouin, B.; Speake, C.; Gersuk, V.; Dussol, B.; Burtey, S.; Pascual, V.; Chaussabel, D.; Chiche, L. Modular transcriptional repertoire analyses identify a blood neutrophil signature as a candidate biomarker for lupus nephritis. Rheumatolog 2017, 56, 477-487. [CrossRef]

108. Banchereau, R.; Hong, S.; Cantarel, B.; Baldwin, N.; Baisch, J.; Edens, M.; Cepika, A.M.; Acs, P.; Turner, J.; Anguiano, E.; et al. Personalized Immunomonitoring Uncovers Molecular Networks that Stratify Lupus Patients. Cell 2016, 165, 551-565. [CrossRef] [PubMed]

109. Scharer, C.D.; Blalock, E.L.; Mi, T.; Barwick, B.G.; Jenks, S.A.; Deguchi, T.; Cashman, K.S.; Neary, B.E.; Patterson, D.G.; Hicks, S.L.; et al. Epigenetic programming underpins B cell dysfunction in human SLE. Nat. Immunol. 2019, 20, 1071-1082. [CrossRef]

110. Pernis, A.B.; Ivashkiv, L.B. '-Omics' shed light on B cells in lupus. Nat. Immunol. 2019, 20, 946-948. [CrossRef]

111. Zhao, M.; Zhou, Y.; Zhu, B.; Wan, M.; Jiang, T.; Tan, Q.; Liu, Y.; Jiang, J.; Luo, S.; Tan, Y.; et al. IFI44L promoter methylation as a blood biomarker for systemic lupus erythematosus. Ann. Rheum. Dis. 2016, 75, 1998-2006. [CrossRef] [PubMed]

112. Wang, Y.F.; Zhang, Y.; Lin, Z.; Zhang, H.; Wang, T.Y.; Cao, Y.; Morris, D.L.; Sheng, Y.; Yin, X.; Zhong, S.L.; et al. Identification of 38 novel loci for systemic lupus erythematosus and genetic heterogeneity between ancestral groups. Nat. Commun. 2021, $12,772$. [CrossRef] [PubMed]

113. Reid, S.; Alexsson, A.; Frodlund, M.; Morris, D.; Sandling, J.; Bolin, K.; Svenungsson, E.; Jönsen, A.; Bengtsson, C.; Gunnarsson, I.; et al. High genetic risk score is associated with early disease onset, damage accrual and decreased survival in systemic lupus erythematosus. Ann. Rheum. Dis. 2020, 79, 363-369. [CrossRef]

114. Ota, M.; Nagafuchi, Y.; Hatano, H.; Ishigaki, K.; Terao, C.; Takeshima, Y.; Yanaoka, H.; Kobayashi, S.; Okubo, M.; Shirai, H.; et al. Dynamic landscape of immune cell-specific gene regulation in immune-mediated diseases. Cell 2021, 184, 3006-3021. [CrossRef]

115. Chung, S.A.; Brown, E.E.; Williams, A.H.; Ramos, P.S.; Berthier, C.C.; Bhangale, T.; Alarcon-Riquelme, M.E.; Behrens, T.W.; Criswell, L.A.; Graham, D.C.; et al. Lupus nephritis susceptibility loci in women with systemic lupus erythematosus. J. Am. Soc. Nephrol. 2014, 25, 2859-2870. [CrossRef]

116. Yang, W.; Zhao, M.; Hirankarn, N.; Lau, C.S.; Mok, C.C.; Chan, T.M.; Wong, R.W.S.; Lee, K.W.; Mok, M.Y.; Wong, S.N.; et al. ITGAM is associated with disease susceptibility and renal nephritis of systemic lupus erythematosus in Hong Kong Chinese and Thai. Hum. Mol. Genet. 2009, 18, 2063-2070. [CrossRef] [PubMed]

117. Yan, R.; Jiang, H.; Gu, S.; Feng, N.; Zhang, N.; Lv, L.; Liu, F. Fecal Metabolites Were Altered, Identified as Biomarkers and Correlated With Disease Activity in Patients With Systemic Lupus Erythematosus in a GC-MS-Based Metabolomics Study. Front. Immunol. 2020, 11, 2138. [CrossRef]

118. Nicolaou, O.; Sokratous, K.; Makowska, Z.; Morell, M.; De Groof, A.; Montigny, P.; Hadjisavvas, A.; Michailidou, K.; Oulas, A.; Spyrou, G.M.; et al. Proteomic analysis in lupus mice identifies Coronin-1A as a potential biomarker for lupus nephritis. Arthrit. Res. Ther. 2020, 22, 147. [CrossRef]

119. Kok, H.M.; van den Hoogen, L.L.; van Roon, J.A.G.; Adriaansen, E.J.M.; Fritsch-Stork, R.D.E.; Nguyen, T.Q.; Goldschmeding, R.; Radstake, T.R.D.J.; Bovenschen, N. Systemic and local granzyme B levels are associated with disease activity, kidney damage and interferon signature in systemic lupus erythematosus. Rheumatology 2017, 56, 2129-2134. [CrossRef]

120. Brown, M.A.; Li, Z.; Cao, K.-A.L. Biomarker development for axial spondyloarthritis. Nat. Rev. Rheumatol. 2020, 16, 448-463. [CrossRef] 